\title{
WHITMAN AND SAROYAN: SINGING THE SONG OF AMERICA
}

\author{
Dickran KouymJian
}

"When WAS THE BEgINNING OF AMERICAN WRITING?” William Saroyan asked in an essay of 1956. His answer:

Opinions must vary. Facts themselves must vary, at least in how they are interpreted. In my opinion American writing began when the unschooled took to the business. This leaves out Emerson, but not Whitman.

Leaves of Grass could not have been written in England, Wales, Scotland, or Ireland.

Whitman himself probably couldn't have written what he wrote anywhere else in the world. In America, European man had an arena at last in which hope could be limitless, and anybody with sufficient intelligence, energy, and ability was free to achieve almost anything. ${ }^{1}$

Saroyan's "anybody" was himself. America was his limitless arena, and he was European man. He had achieved. He regarded himself a direct literary descendent of Whitman. Whitman's struggle for recognition was like his own; Whitman's battle with the establishment was followed by him boldly; Whitman's universalism was his, too.

There are several ways one might speak about Saroyan and Whitman: (1) by enumerating the parallels in their lives; (2) by analyzing Saroyan's references to the poet who died sixteen years before his own birth; (3) by examining the influence of Whitman on Saroyan's writing; (4) by comparing their world view.

Like Walt Whitman, William Saroyan was born into an honorable, if poor, middle-class family. His father was a Protestant minister as a result of American missionary work in his home town, the city of Bitlis in the western part of historical Armenia. Saroyan was the youngest of four children and the only one born in the United States, where the family sought refuge anticipating correctly the continued Ottoman Turkish oppression that was to lead to the genocide of the Armenians just ten years after their arrival in America. Disenchanted by the public school system, at thirteen Saroyan, like Whitman, was able to escape it before his imagination was permanently crippled. Both men undertook practical proto-literary employment: Saroyan with the Postal Telegraph Company, Whitman as a printer's journeyman.

Because the two refused the conventional academic path into the world of American letters, they shared a life-long disdain for those institutions that guided literary fashions and dictated behavioral norms. 
Saroyan was passionate and boisterous. He rejected conformity. He was immodest. He had little use for the niceties of polite society. He would not flatter to advance his career. He would not follow the accepted way of doing things if it was unprincipled or not to his liking. He was stubborn about his personal integrity. Saroyan probably imagined that Whitman had similar personality traits.

No doubt one consequence of the meager formal education of Saroyan and Whitman was their rejection of the accepted canons of literary composition, precisely those learned in classrooms. Free of formalism, they were able to liberate the media in which they wrote. Whitman's innovation in the use of free verse in long rhythmical lines with a natural organic structure, his fresh subject matter with its glorification of the body and exaltation of sexual love, find their parallel in Saroyan's rejection of structure and plot in his stories and in the formlessness of his plays. Both writers used the preface to explain their work to reader and critic.

Whitman published his first book, Leaves of Grass, when he was 37 and it was a failure. Saroyan published his first book, The Daring Young Man on the Flying Trapeze (1934), at age 26, and it was a great success. Literary critics were quick to see Whitman as a new and audacious voice in American literature; Emerson, by then of the establishment, endorsed him. Saroyan also had critical acclaim, but too often the academics were confused by his works, especially the plays, accusing Saroyan of neglecting form, of being too facile, of surrealistic fantasy, and of working too quickly and carelessly. The "New Critics," with their insistence that great literary work be evaluated in terms of conventions of form and technique, were especially hard on him.

In the essay "What Makes American Writing American" quoted above, Saroyan goes on to say:

There's no telling what doubts may have been in Whitman's heart about the kind of "poetry" he was writing and how it would be received. It isn't unlikely that he sometimes believed he was making a fool of himself, because even in our time even our best writers, whenever they hit upon a new order of writing which they feel they must pursue, have doubts about what they are doing, and what the critics and the public will think about it. $^{2}$

Again in this passage the California writer is talking as much about himself and his new order of writing as he is about Whitman.

"Whitman published Leaves of Grass at his own expense," says Saroyan, continuing, "it was an instantaneous flop, although Emerson hailed it in a letter to Whitman. Emerson might accurately have said the stuff wasn't poetry, but he didn't. And the fact is it didn't matter whether it was poetry or not. No Englishman, not even an unschooled one, could have written as Whitman had, because none would have been 
willing to do so; none would have been willing to be so likely to be taken for a lunatic."3

By attributing the merits of Whitman's creativity in part to his lack of schooling, Saroyan is again referring to himself. Only someone with a streak of craziness would have undertaken such a task; Saroyan often boasted about the madness in his own clan, and by implication in himself; thus again he fits the profile of Whitman as writer.

In his concluding remarks on Whitman, there is further reinforcement of the parallels between himself and the poet:

Whitman did not belong to the world of art. Whatever it was that he wrote, it just wasn't understood to be the proper subject of poetry. As for his manner of writing, it was practically anarchistic. Whitman belonged to the world. He and his work were the same thing, as in the founder of a religion. If he was anything at all he was a personality or, if you prefer, a personage, in the European sense-a personage without any inherited, social, or economic right to such a designation. He was Whitman, pure and simple. He was Anybody become Somebody by saying so, which is the essence and meaning of America. He may in time be named the first true American - the upstart with great if impudent confidence who does something different that turns out to be more than merely eccentric or ill-mannered. ${ }^{4}$

The subjects of Saroyan's own stories and plays were not the accepted ones either, and he too was an upstart who made his success by willfullness. "This ego push is by no means obsolete among us," says Saroyan. "It persists all over the place, in areas of potential magnificence no less than in areas of inevitable absurdity-from subtle discoveries in science to acts of attention-attracting for what is known as publicity." Again, inevitably seeing himself in Whitman, Saroyan concludes: "Whitman was a loner, as most Americans are at heart. $\mathrm{He}$ belonged to no school, and founded none."

The dedication to the 1958 anthology The William Saroyan Reader begins, "To the writers who impelled me to write, Jack London, Guy de Maupassant, Charles Dickens, Anton Tchekhov, Mark Twain, August Strindberg, Maxim Gorky, Ambrose Bierce, Leo Tolstoy, Molière, George Bernard Shaw, Walt Whitman, Henri Fréderic Amiel, Henrik Ibsen, Sherwood Anderson, and Solomon, the son of David, who wrote The Book of Ecclesiastes." "This is perhaps the most complete catalogue of literary influences Saroyan ever admitted to. Three years earlier in "Earthly and Heavenly Voices," written for High Fidelity Magazine, he asks, "If records of the voices of the writers of the past were available, whom would I want to listen to? Well, I would especially like to hear voices of Guy de Maupassant, Leo Tolstoy, Jack London, Mark Twain, Anton Chekhov, Charles Dickens, Goethe, Strindberg, Ibsen, Hamsun, Ambrose Bierce, Joaquin Miller, Maxim Gorky, Balzac, Walt Whitman, Poe, and O. Henry." Even earlier in the 1948 story "A Walk in New York," published only in 1968, he says "What young ghost of great men 
the walker greets as he goes: Washington, Franklin, Lincoln, Poe, Stephen Foster, O. Henry, Walt Whitman, Jack Johnson, Caruso, Knut Hamsun, George Bellows, Sousa, . . . . In that same year, 1968, Whitman turns up again in Saroyan's letter to Carl Sandburg published in the Saturday Evening Post:

When I had been a telegraph messenger in Fresno, aged thirteen, working the nightshift after school ... I used to write poems on the company typewriters, because I had read everything on the poetry shelf at the public library-Walt Whitman, Vachel Lindsay, Edgar Lee Masters, and Carl Sandburg, among others, and I believed I ought to write stuff like that, too, but in the end it turned out that my first book was a collection of short stories, and after that I wrote fewer and fewer poems and hardly ever offered them to an editor. $^{8}$

In Obituaries, a vast reflection on death published in 1979, Saroyan speaks of his disappointment that Franklin Roosevelt read mystery stories: "In those days (the late 1930s) . . . I had the notion that a President of the United States, with such an affectation of fondness for the people, or at any rate the majority of the people, would find it in order to go continuously to the waters provided by Walt Whitman, Mark Twain, and, for instance, O. Henry."9

Beside these almost casual references there were the more serious ones, like the essay on American writing already cited, which reveal Saroyan's liking of Whitman and his debt to him. In After Thirty Years: The Daring Young Man on the Flying Trapeze (1964), a reprint of his first great success accompanied by thirty-eight short pieces reminiscing on writing, Saroyan attributes the poetic quality of his early prose to Whitman: "The thing I knew in 1934 was that it was necessary to write a story every day. . . . There were no other restrictions. The story could be a letter. . . . Each nevertheless was also a story. Some of the . . . stories were jazz, pure and simple, but jazz in writing. Some were prose poems, something like Walt Whitman's broken prose, or poetic prose, but more in feeling than in the use of language." 10 The theme of poetry writing is picked up again on the last page of Saroyan's last book, the posthumous memoir Births:

Rembrandt was an Armenian, the Armenians say . . . there is evidence that he was, there is also evidence that he wasn't. He was born, that's all. And so were you. Forget it. Skip it. Let it go. I forget. I even forget what I dreamed last night, and what a loss that must be to you, Oh friend in the future, as Walter Whitman would say, or Mr. Walter Whitman had he also been an executive at a bank or at an insurance company, like T.S. Eliot and Wallace Stevens. Everybody who writes a poem isn't a bum, you know? Some of the boys settle themselves into chairs of responsibility and even authority. God bless them, and you, is all I can say. God really really really bless them. ${ }^{11}$

From Saroyan's use of Whitman conceits in his first stories to his respect for Whitman the poet at the end of his life, there was a consis- 
tent and constant evocation of the author of Leaves of Grass. This book he held in such high esteem that it came first in his list of non-dramatic works for theatrical production. In 1941 Theatre Arts invited Saroyan to suggest a repertory for a National Theatre. He offered a list of twelve items. It was published the following year in the preface of his book Razzle-Dazzle:

They are . . . potential American theatrical material, ... these should constitute the beginning of a real American stage art, with a basis in the past, a present direction, and a constant potential for the future. I am choosing my plays from those artful and real sources of the temper and texture of inner and outer American life that seem to be urgently in need of isolation and absorption by the American race. . . .

1. Leaves of Grass, by Walt Whitman; adapted by Christopher Morley and William Rose Benét; all people in the play will be anonymous; no story; no plot; pure theatre. Instead of sets, colors and projected images, probably by Boris Aronson. No intermissions. A couple of hours straight through. Music by Paul Bowles. ${ }^{12}$

By choosing Leaves of Grass first, Saroyan was choosing his own work. The Time of Your Life had just won him the New York Drama Critics Award and the Pulitzer Prize. The play had no story and little plot. The characters seemed to make their stage entrances haphazardly as customers might have entered Nick's Bar. Paul Bowles had written the music for My Heart's in the Highlands, Saroyan's first play. Thus, the identification of Whitman the poet and the poetic Saroyan was firmly established at the beginning of the California writer's career and was to endure to its end.

What parts of Saroyan's style and subject matter can be in part attributed to his reading of Whitman ${ }^{13}$ Saroyan's use of catalogues is like Whitman's, though often they are merely lists of names and objects or just synonyms. Saroyan championed the common man in all of his writing; he insisted that no man or woman is more important or more worthy than any other. He often provocatively professed his belief in the singularity of all humankind. In Haratch, one of the posthumously published plays, Saroyan (as a character in his own play) is asked if he did not say more than once that everybody is Armenian. He replies "Oh, yes, I did, but I was informed that a Jewish writer had said that same thing . . . before I had done so . . . and how right he was: Everybody is a Jew. In other words, everybody is everybody else."14 The idea is even more dramatically advanced in the same play. In response to the question "Who is an Armenian?" a character answers, "An Armenian is a Turk who says I am an Armenian."

The urge to identify the self with the universe, the "universalizing" of experience, is a quality Saroyan shares with Whitman. That we are all the same person underneath the superficial masks of daily social interaction is for him a visible truth. Behind this vision of life is the 
conviction that we are all tied together by the bonds of common humanity - within each human breast beats the same cosmic energy.

Whitman's focus on the self fitted Saroyan well. He wrote of self and from self. The dozen or so autobiographical books by Saroyan review the major events of his life over and again with special existential interest on how he became what he was. In Saroyan's last play, Warsaw Visitor, ${ }^{16}$ written in 1980 only months before his death, the three main characters are all himself: Moustache, an American writer named Saroyan traveling to Warsaw, the Devil serving as the writer's alter-ego and foil, and Saroyan, the author of the play who, from time to time, comes on stage to talk to the audience.

The celebratory impulse in Saroyan's writing can be traced directly back to Whitman's singing of self in Leaves of Grass; Saroyan seeks the experience of being; he wants to go straight to the core of thingsenergetically, immediately, passionately. $\mathrm{He}$ is, in Philip Rahv's conception, a "redskin" like Whitman and William Carlos Williams. He is emotional, naturalistic, nativist, energetic, and in some sense uncultured. ${ }^{17}$

Saroyan's work is thus a great deal more complex and diverse than many critics have acknowledged. His writing is a blend of the affirmative, mystical, and rambunctious qualities of the American romantic sensibility, but tinged with the sorrow of the Armenian experience. As David Calonne has remarked, "He praises and broods, moves outward toward the world in extrovert fashion and holds closely inward to himself the loneliness of the poet."18

Whitman supplied Saroyan a model of transcendence and bravura. In the essay-story "Myself upon the Earth" from The Daring Young Man on the Flying Trapeze, Saroyan writes: "Every life is a contradiction, a new truth, a new miracle, and even frauds are interesting. I am not a philosopher and I do not believe in philosophies; the word itself I look upon with suspicion. I believe in the right of man to contradict himself." 19 The thought and the language are from Whitman's Leaves of Grass: "Do I contradict myself? / Very well then I contradict myself, / (I am large, I contain multitudes)." For Saroyan as for Whitman, the contradictions of experience must be embraced; life's paradoxes cannot be overcome by forcing them into "systems" or philosophies. The inner self must be allowed to grow free of the false twistings and "proofs" of logical constructions. ${ }^{20}$

Saroyan emphasized imagination and the idea of play in his dramatic work. It confounded the critics and sometimes even the audiences. This concept is, however, very much a part of the American literary tradition. It is an echo of Whitman's "I loaf and invite my soul," and his exaltation of the limitless potentialities of a life lived with improvisational ease and spontaneity. ${ }^{21}$ 
Saroyan's first success, the story "The Daring Young Man on the Flying Trapeze," has, as he himself acknowledged, a Whitman-like feeling. Its short first part, subtitled "Sleep," is a grand catalogue of the life-images of a writer:

Horizontally wakeful amid uni. sa' widths, practising laughter and mirth, satire, the end of all, of Rome and yes of Babylon, clenched teeth, remembrance, much warmth volcanic, the streets of Paris, the plains of Jericho, much gliding as of reptile in abstraction, a gallery of watercolors, the sea and the fish with eyes, symphony, a table in the corner of the Eiffel Tower, jazz at the opera house, alarm clock and the tap-dancing of doom, conversation with a tree, the river Nile, Cadillac coupe to Kansas, the roar of Dostoyevsky, and the dark sun.

The earth, the face of one who lived, the form without the weight, weeping upon snow, white music, the magnified flower twice the size of the universe, black clouds, the caged panther staring, deathless space, Mr. Eliot with rolled sleeves baking bread, Flaubert and Guy de Maupassant, a wordless rhyme of early meaning, Finlandia, mathematics highly polished and slick as a green onion to the teeth, Jerusalem, the path to paradox.

The deep song of man, the sly whisper of someone unseen but vaguely known, hurricane in the cornfield, a game of chess, hush the queen, the king, Karl Franz, black Titanic, Mr. Chaplin weeping, Stalin, Hitler, a multitude of Jews, tomorrow is Monday, no dancing in the streets.

$\mathrm{O}$ swift moment of life: it is ended, the earth is again now. ${ }^{22}$

Throughout the story the physical body of the young starving writer, with all his senses put in relief by hunger, is contrasted to the artistic flight of his literary imagination, his soul. Surely Saroyan was working in Whitman's realm. In the end the writer dies. The final lines describing this death are transcendent, almost as mystical as Whitman in Section 5 of "Song of Myself": ${ }^{23}$

Then swiftly, neatly, with the grace of the young man on the trapeze, he was gone from his body. For an eternal moment he was all things at once: the bird, the fish, the rodent, the reptile, and man. An ocean of print undulated endlessly and darkly before him. The city burned. The herded crowd rioted. The earth circled away, and knowing that he did so, he turned his lost face to the empty sky and became dreamless, unalive, perfect. ${ }^{24}$

The tendency to consider Saroyan an ethnic writer ignores his obsession with American letters. Today, ethnic writers are often dismissed by academics and critics. Why should non-ethnics bother reading works labeled "ethnic"? The very term "ethnic" literature is taking on a pejorative meaning. Such an optic ignores Saroyan's influence on a generation of American writers and filmmakers-Kerouac, Salinger, Brautigan, Peckinpah. The strong Whitmanesque affirmation of the self is evident in Saroyan's prefaces, pronouncements and autobiographical memoirs. Make no mistake that we are dealing here with an American trait shared by Whitman, Thoreau, Wolfe, Miller and Saroyan. 
Nothing underlines this attachment to American letters more than Saroyan's respect for Whitman, Saroyan's homage to the individual who forged a new path in American poetry, one that Saroyan followed and extended into the areas of the story and the stage. Like Whitman, Saroyan sang America, an America diverse in its pursuits and universal in its reach. If Walt Whitman looked West, one young CalifornianWilliam Saroyan-caught his glance, understood its meaning, and incorporated the message into his own creation.

California State University, Fresno

\section{NOTES}

1 William Saroyan, I Used to Believe I Had Forever, Now I'm Not So Sure (New York: Cowles, 1968), 35; reprinted from The Reporter (September 1956).

2 Saroyan, I Used to Believe, 135.

3 Ibid.

4 Ibid.

5 The William Saroyan Reader (New York: Braziller, 1968).

6 "Earthly and Heavenly Voices," I Used to Believe I Had Forever, 49-50, originally in High Fidelity (January 1955).

7 Saroyan, I Used to Believe I Had Forever, 199. The list continues: Ty Cobb, J. P. Morgan, [Arshile] Gorky, William Jennings Bryan, Eugene O'Neill, Christy Mathewson, John Barrymore, Billy Sunday, Theodore Dreiser, George Gershwin, Babe Ruth.

8 In the August 24, 1968 issue as part of six letters later incorporated into Letters from 74 rue Taitbout or Don't Go But if You Must Say Hello to Everybody (New York: World Publishing, 1969), 125-132.

9 William Saroyan, Obituaries (Berkeley: Creative Arts, 1979), 122.

10 William Saroyan, After Thirty Years: The Daring Young Man on the Flying Trapeze (New York: Harcourt, Brace and World, 1964), 124-125.

11 William Saroyan, Births (Berkeley: Creative Arts, 1983), 121.

12 William Saroyan, Razzle-Dazzle (New York: Harcourt, Brace, 1942), xxii.

13 Howard Floan, William Saroyan (New York: Twayne, 1964), was also the first to add Whitman's name to those of Sherwood Anderson, de Maupassant, George Bernard Shaw, and Mark Twain as a major influence on our writer. David Calonne, in his William Saroyan: My Real Work is Being (Chapel Hill: University of North Carolina Press, 1983), pursued the matter.

14 William Saroyan. An Armenian Trilogy, ed. Dickran Kouymjian (Fresno: The Press at California State University, Fresno, 1986), 169. 
15 An Armenian Trilogy, 153. The passage goes on to say: "It is a decision open to all people, and only Armenians have ever wanted to be Armenians, everybody else has not made a decision but has gone right on being whatever it was he believed he was, anyhow."

16 William Saroyan, Warsaw Visitor and Tales from the Vienna Streets, ed. Dickran Kouymjian (Fresno: The Press at Ci ufornia State University, Fresno, 1991).

17 The information is found in Steven Axu'rod, Robert Lowell: Life and Art (Princeton: Princeton University Press, 1978), 10-11 as quoted by Calonne, William Saroyan, 8-9. The full citation is: "American literature composes itself into a debate between 'palefaces' and 'redskins.' The 'palefaces' (Henry James, T.S. Eliot, and Allen Tate would belong to this party) produce a patrician art which is intellectual, symbolic, cosmopolitan, disciplined, cultured. The 'redskins' (Walt Whitman and William Carlos Williams would tend to belong here) produce a plebeian art which is emotional, naturalistic, nativist, energetic, in some sense uncultured. . . . All such formulations attest to a basic bifurcation in American literature between writers who experience primarily with the head and those who experience primarily with the blood."

18 Calonne, William Saroyan, 8-9.

19 Saroyan, After Thirty Years, 162.

20 Calonne, William Saroyan, 21-22.

21 Calonne, William Saroyan, 73.

22 Saroyan, After Thirty Years, 136.

23 The precise quotation: "Swiftly arose and spread around me the peace and knowledge that pass all the argument of the earth."

24 Saroyan, After Thirty Years, 142. 